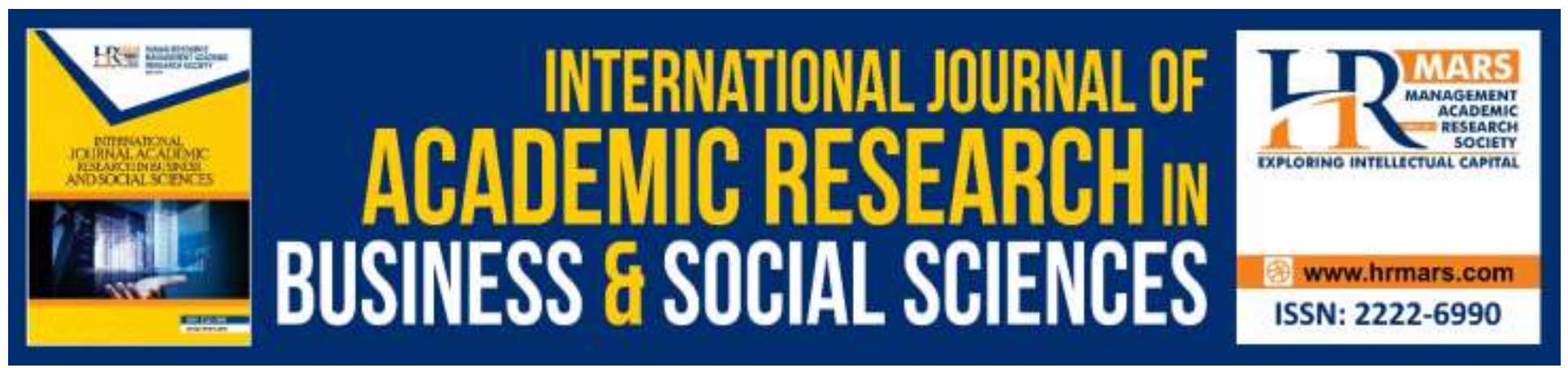

\title{
Factors Influencing Sustainability of Community Operated Water Projects in Central Nyakach Sub-County, Kisumu County, Kenya
}

Syprose Nyakwaka, Muronga Kadurenge Benard

To Link this Article: http://dx.doi.org/10.6007/IJARBSS/v9-i7/6096

DOI: $10.6007 /$ IJARBSS/v9-i7/6096

Received: 03 May 2019, Revised: 11 June 2019, Accepted: 28 June 2019

Published Online: 24 July 2019

In-Text Citation: (Nyakwaka \& Benard, 2019)

To Cite this Article: Nyakwaka, S., \& Benard, M. K. (2019). Factors Influencing Sustainability of Community Operated Water Projects in Central Nyakach Sub-County, Kisumu County, Kenya. International Journal of Academic Research in Business and Social Sciences, 9(7), 108-130.

Copyright: (C) 2019 The Author(s)

Published by Human Resource Management Academic Research Society (www.hrmars.com)

This article is published under the Creative Commons Attribution (CC BY 4.0) license. Anyone may reproduce, distribute, translate and create derivative works of this article (for both commercial and non-commercial purposes), subject to full attribution to the original publication and authors. The full terms of this license may be seen at: http://creativecommons.org/licences/by/4.0/legalcode

Vol. 9, No. 7, 2019, Pg. $108-130$

Full Terms \& Conditions of access and use can be found at http://hrmars.com/index.php/pages/detail/publication-ethics 


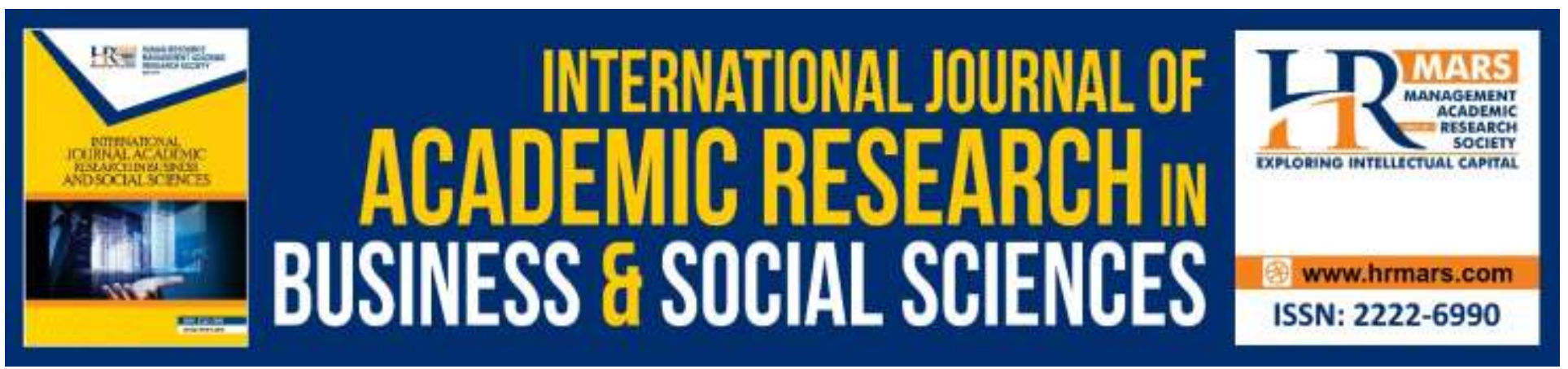

\title{
Factors Influencing Sustainability of Community Operated Water Projects in Central Nyakach Sub- County, Kisumu County, Kenya
}

\author{
Syprose Nyakwaka \\ The Catholic University of Eastern Africa, Kenya, NAIROBI, Kenya \\ Dr Muronga Kadurenge Benard \\ University of Kigali, Rwanda \\ E-mail: nyakwakasyprose@gmail.com,bmuronga@uok.ac.rw
}

\begin{abstract}
Sustainability of community based and managed rural water projects in Kenya remains a challenge as it has ever been. In spite of concerted efforts to transfer ownership of rural water projects to beneficiary communities and to increase participation of the communities in the operation and maintenance of these facilities, more than a third of all rural water projects fail within the first few years of development. This paper examines the determinants of sustainability of community operated water projects in Central Nyakach Sub-County, Kisumu County, Kenya. This paper is based on an empirical study that sought to examine how community participation influences sustainability of community water projects in in Central Nyakach Sub-County of Kisumu County, Kenya. Employing a descriptive cross-sectional design, and from a target population of 320 residents of Nyakach SubCounty, the purposeful sampling technique was used to draw a sample of 175 respondents. Quantitative data was analyzed using descriptive statistics of percentages and means. Content analysis was also done for qualitative data. The results revealed that community members' involvement in all the project phases from planning through to the building and management of the community water projects was low. The study concluded that there was significant influence of inadequate community participation on the lack of sustainability of community water projects in Central Nyakach Sub-County. The study recommended that it would be prudent for development partners in water projects to allow the community members to identify their needs, prioritize the type of water projects, actively participate in the budgeting process, participate in implementation as well as actively undertake monitoring and evaluation of project activities and processes.
\end{abstract}


INTERNATIONAL JOURNAL OF ACADEMIC RESEARCH IN BUSINESS AND SOCIAL SCIENCES

Vol. 9, No. 7, July, 2019, E-ISSN: 2222-6990 @ 2019 HRMARS

\section{Background to the Study}

This paper is based on a study that was done in 2018 about the factors that influence the sustainability of community water projects in central Nyakach Sub-County of Kisumu County, Kenya. This section (1.0) examines the status of management of community water projects. Both general and empirical literature has been reviewed.

\section{General Literature on Management of Water Projects}

There is individual nation as well as global effort aimed at meeting the Sustainable Development Goal (SDG) number 6 which is about ensuring availability and sustainable management of water and sanitation for all people (United Nations, 2018). However, many nations are far from achieving this goal. Kenya for instance, is in the top ten list of countries with the largest population without access to safe drinking water (Alida, 2012; WHO \& UNICEF, 2012); whereas increased investment in the development of rural water projects in the last decade by both governments and development partners has not resulted in the desired levels of service as was anticipated.

Access to safe drinking water is a basic human need necessary for both the wellbeing and socio-economic development of populations living in rural Kenya. Notwithstanding the effort to increase access to water, many rural water supplies have either stopped operating or are not operating optimally, and this has resulted to water scarcity for populations living in the rural areas of Kenya (Mwangangi \& Wanyoike, 2016). Many of the dysfunctional water sources are operated by community based organizations such as community Water and Sanitation (WASH) Committees, Water User Associations or Women Groups.

The role of the communities in the operation, maintenance and management of rural water projects was first described in the Sessional Paper No. 1 of 1999 on National Policy for Water Resources Management and Development (Government of Kenya [GoK], 1999). The paper defined the involvement of communities in project development in all stages including planning, implementation, operation, and maintenance of water related projects in light of the changing economic conditions and the increasing service provision burden to the Kenya Government. The paper further recommended institutional steps to be taken to facilitate the role of communities in the operation and maintenance of rural water projects. Increasing the participation of the communities in the management of water projects was intended to create a sense of ownership of the projects by communities. In line with recommendations of the Sessional Paper No. 1 of 1999, operation and maintenance of rural projects has largely been transferred to the beneficiary communities over the years. Most rural water supplies today are community operated and managed. In the subsequent water sector reforms and legislation based on the Water Act of 2002, a provision was made for the establishment of groups or firms that own or want to operate water projects as Water Service Providers. Such groups or firms would operate water systems under license on behalf of user populations (GoK, 1999).

According to Macharia, Mbassana and Oduor (2015) many rural water project systems in Kenya did not meet the license criteria and consequently continue to be operated by community groups without regulation. The sustainability of these community-based and managed water projects therefore remains a challenge to progress in the Water Sector and has implications for the attainment of the Water Sector objectives in Kenya, the Kenya Vision 2030, and the Sustainable Development 
Goals (SDGs) among other policy instruments like the county development plans. This has further implications for the socio-economic development of the affected populations, child survival and development indicators for Kenya. The United Nations General Assembly has declared access to safe drinking water a fundamental human right; and a number of criteria have been used to specify the content of this right: Availability, quality, acceptability, accessibility and affordability. Water is a basic human need and is important for human survival (UN 2010).

A number of reports and policy instruments have given estimates of current access levels to safe water in Kenya where it is estimated that more than 80 per cent of Kenya's population live in the rural areas (Kanyanya, 2014). According to the WHO/UNICEF (2012), only 52 per cent of the population living in rural Kenya has access to improved drinking water sources as compared to 82 per cent of the urban population in 2010; the national average is 59\%. The draft National Water Policy of 2012 (GoK, 2012) put current rural coverage at below 50 per cent and attributed the low coverage to the type of sources (hand pumps, springs, wells and small pipe schemes) which have complicated stocking requirements for spare parts and repair efforts. On the other hand, the African Ministers Council on Water (AMCOW- Africa Ministerial Council on Water-, 2012) puts coverage in Kenya in 2010 at only 42\%. The Millennium Development Goals for water and sanitation had targeted having the population with access to safe water by 2015 (UN, 2008). However, this was not attained in Kenya.

The MDG Report for 2012 noted that Kenya was already off course in achieving the MDG on water and sanitation. According to the draft National Water Policy (NWP) 2012 (GoK, 2012), most of the rural water services systems are still not sustainable because of inadequate operation by communities leading to breakdown of facilities and low access rate, poor water quality and increased disputes. Disparities in access to safe water are even more severe in the arid and semi-arid lands (ASALs) where there is insufficient densification of water points (GoK, 2012). To underscore the importance of access to safe drinking water, the Bill of Rights under article 43 of the Constitution of Kenya (GoK, 2010) states that access to safe water and safe sanitation is a right, which the Kenyan Government should strive to provide.

It is estimated that $35 \%$ of improved rural water supply points in sub-Saharan Africa are nonoperational and this scenario is no exception in Kenya (Ababa, 2013). Quoting USAID Kenya; Oino, Kirui, Towett and Luvega (2015) note that despite Kenya Government's effort of setting ambitious targets to provide access to safe drinking water and basic sanitation facilities to $85 \%$ of the population by 2015 and $100 \%$ by 2025 in line with SDGs, the country still faces considerable challenges in reaching the Sustainable Development Goals for water and sanitation. According to Mamburi (2014), access to safe water supplies throughout Kenya is 59 percent with access in rural areas remaining as low as 47 percent, with reliance on unprotected wells, springs or informal water providers. This implies that Kenya still has a long way to achieve its targets on access to quality and safe water.

The draft NWP of 2012 (GoK, 2012), further aligns the sector with the new Constitution of Kenya enacted in 2010 based on the guiding principles. The right to water with pro-poor orientation, participatory approach to water development and management and good governance practices at all levels is envisaged. The Policy objectives of the draft further include progressively achieving universal rights to water supply and sanitation for all by 2030 in the rural and urban areas (GoK, 2012). 
The Ministry of Water and Irrigation in Kenya has been implementing the water sector reforms since the enactment of the Water Act 2002 (GoK, 2012) to improve sector efficiency and overall performance but more importantly, create new decentralized institutional framework to inter alia - accelerate water service provision. As a result, the sector's approved development budget rose seven fold in the recent past from Kenya Shillings 4.2 Billion in the 2004/2005 financial year to over Kenya Shillings 30 Billion in the 2015/2016 financial year. To complement this effort and in line with the sector objectives of improving access to safe water for un-served populations, UNICEF implemented a six year (2008-2014) water supply program in 20 rural districts with least access indicators with the aim of reaching 1.6 million people. More than 850 sources including 100 rehabilitations were completed by the end of 2012. However, it has become evident that increasing coverage does not equate to increased access due to a high rate of failure of water projects (Oino et al., 2015). This points to a difficult situation in which so much effort has been done but the results do not reflect this effort.

The GoK (2012) indicates that there are approximately 680 piped water systems that provide over 740,000 water connections throughout the nation; and an additional 350 community run water schemes (GoK, 2012). A big percentage of these connections are however inactive due to poor management and maintenance (GoK, 2007), making water projects failure a problem that can be selfperpetuating. This is given credence by Van Loon and Droogers (2006) who in their study on Water Evaluation and Planning System in Kitui (Kenya), point out that bad experience on unsuccessful water projects in the past alienates people and makes them likely to be hostile towards future initiatives.

According to Themartic Group (2005), among the 24 million rural dwellers in Kenya then, about 10 million had access to improved water supply either through piped water or point source systems. Of those with access, $30 \%$ of them were served by community based water supply schemes which were developed by self-help groups through donor support and government institutions. Most of these community based water supply schemes are inactive yet the government has continued to establish more water projects with little regard to rehabilitation of non-functioning ones (Themartic Group, 2005). This brings to the fore the need to have prudent planning and management of community water projects in Kenya.

The challenge of managing water projects has also been studied by Alida (2012). Alida (2012) noted that despite relative success in the provision of new rural water infrastructure in the last two to three decades, evidence show that between 30 to 40 per cent of facilities either do not function or are operating below capacity. In Kenya, about 25 to 30 per cent of the recently completed community managed rural water project facilities become dysfunctional within the first three years following completion (Alida, 2012). Consequently, the Kenya national government and development partners had at that time started to recognize the big magnitude of the problems associated with poor sustainability of rural water projects (IRC, 2011).

Project sustainability can defined as the ability of a system of any kind to endure and be healthy over the long term. Macharia et al., (2015) observe that project sustainability refers to the benefits realized, maintained and continued after the project has been handed over to the beneficiaries. Sustainability may also be defined as the ability of an organization to develop a strategy of growth and development that continues to function indefinitely. This study will adopt the definition of sustainability as the process of ensuring an adaptive prevention system and sustainable 
infrastructure and interventions that can be integrated into ongoing operations to benefit diverse stakeholders (Mwangi, 2014).

Other studies conducted on water projects (like Ngetich, 2009) have shown that most water projects did not function to the full capacity. A study conducted by Habtamu, (2012) showed that most water projects decline in performance shortly after external support is withdrawn. Similarly, studies by Rimbera (2012) and Ali (2012) reported that lack of project sustainability was due to low level of community awareness, approaches used by developers and lack of proper feasibility studies. To address this challenge, Gatari, Mbabazi and Shukla (2016) note that adoption of technology and the effective operation and maintenance are key in sustainability of community based water projects. On his part, Habtamu (2012) found that sustainability rate of rural water supply systems increases as a result of communities owning and managing their schemes, existence of management organization at the village level, protection of the water points, cost recovery for operation and maintenance, technology type and availability of spare parts.

\section{Empirical Literature on Management of Water Projects in KENYA}

Studies on community participation in the sustainability of community water projects, as well as water extraction technologies on the sustainability of community water projects have been examined in this section.

\section{Community Participation in the Sustainability of Community Water Projects}

Community participation in the sustainability of community water projects is one of the two themes that form the focus of this study; over which a lot of literature exists. Mwangi (2014) investigated the determinants of sustainability of community water projects in Kieni East District, in Nyeri County of Kenya. Employing a descriptive survey design, and purposefully sampling respondents from various households, Mwangi (2014) found a high community participation level of $80 \%$ in conservation of water resources. However, Mwangi (2014) did not explain why sustainability could not be attained even in projects where community participation was at this good level of $80 \%$.

In another study, while addressing the success rate of water projects, Mamburi (2014) noted that operational failure rates from different African Countries range from 30 to 60 percent. In Kenya, it is a common phenomenon to find nonfunctional water systems just a few years after implementation. According to Mamburi (2014), some of the factors attributed to this include lack of adequate protection like failure to fence off the water pans, vandalism of solar pumping systems for boreholes, non-operational shallow well hand pumps and wind mills. The underlying factors for this state of affairs ought to be studied and documented to form a basis for action and learning. According to Mamburi (2014), the starting point is to plan for communities to be involved in all stages of the project, from the planning through to the building and also the management of systems. Mamburi (2014) further observes that active community participation also enhances and leads to actualization, maintenance and sustainability of their projects. This is in tandem with Olukotun (2008) who observes that through community participation, community members gain ownership and skills for a collective action that enhances sustainability of projects. Mamburi (2014) also concurs with World Bank (1981), Olukotun (2008), and Rimbera (2012) that community participation enhances skill development and a sense of ownership that leads to effective implementation and sustainability of 
projects. Although Mamburi (2014) has detailed the challenges that face community water projects, he did not address the reason as to why even projects that have good community participation could not be sustained.

Community participation in water management projects can range from attending community meetings and even voting for committee members on the least and on the higher side, a person can serve as a committee member (Kanyanya, Kyalo, Mulwa \& Matula, 2014). The second aspect relates to provision of labour where a community member can choose to donate manual labour, or even offer skills to give services to the community water project. Participation can also come in the form of physical resources held by community members who can provide material resources for the water project in the form of construction material like bricks, hay, trees or construction tools like spades, wheelbarrows, hammers and nails. Beyene (2010) observe that community participation could also be in monetary resources/donations which is generally most demanded by development initiatives and is considered by many to be a less active form of community participation because relatively little time is involved.

Other researchers on community participation - Oino et al., (2015) - suggest that in order to empower the community, it is important to have community members identify their own needs, analyze the factors that lead to the needs, and draw up community action plans (CAP) to address them. Furthermore, respect for and the use of community's inherent knowledge and capacities allow the community to cultivate innovative approaches to address their own problems. Finally, before the implementing agency hands over the project to the community, it should design exit plan and sustainability plan to promote continuity of the project after the agency has left. After the implementing agency has left the project, the sponsors should only come in for technical guidance as project sustainability is dependent much on the community's full participation. Oino, et al. (2015) further note that community participation is key to the sustainability of projects as it entails the genuine involvement of local people as active participants and equal partners whose concerns and experience are intrinsic to the project's success. The critical issue about community participation which Oino, et al. (2015) have not addressed relates to why projects with high community participation still fail or operate at below optimum levels.

\section{Water Extraction Technologies and Sustainability of Community Water Projects}

Various water extraction technologies are in use for community based water projects. However, across the globe, many such technologies are either non-functional or in need of repairs; and Mamburi (2014) found that in India, rural regions of Mali, and Ghana, the factors responsible for the non-functioning of boreholes range from extreme low yields, inability to raise funds to acquire spare parts, to lack of access to spare parts. Alida (2012) investigated the financial sustainability of rural water supplies in Western Kenya in which one of the research objectives was to compare how different technology types influenced financial sustainability. Employing descriptive survey design and analyzing data using weighted scores, Alida (2012) found that all hand-pumps under community management scored low on financial sustainability. For the government managed motorized pumps, the payments were not good enough to cover the costs.

About water extraction technologies, Alida (2012) noted that two types of springs were common, namely unprotected springs and protected springs. In the latter case, the water source is 
encased in concrete in order to allow water to flow out from a pipe instead of seeping from the ground. After the construction of this structure, the operation and maintenance consists of keeping the surroundings clean and repairing pipes or cracks in the structure (Alida, 2012). The other form is a hand dug well without a pump. These wells are found within the homesteads of the rural families. Water is manually drawn from these wells using a bucket with a rope. Operation and maintenance requirements for this technology are cleaning of the well site and drain, repairing of apron (if present) and rehabilitating with gravel or piping material (Alida, 2012).

According to Lake Victoria South Water Services Board (LVSWSB) and Lake Victoria North Water Services Board (LVNWSB), in parts of Central Nyakach Sub-County, in areas where less springs and surface water sources are found, hand pumps are used on wells and boreholes (Oraro 2012). A hand pump is a simple technology to manually pump groundwater from a well or borehole. Small repairs for the hand pumps include the replacement of worn cup seals and washers, straightening of pump rods and replacement of corroded lock nuts. Major repairs include the replacement of the pump rods, plunger, foot valve, cylinder, rising main or pump handle (Alida, 2012; Brikké, 2000).

The fourth water extraction technology involves a well or borehole with motorized pump. This technology (which is also found in water supply in Nyakach Sub-County) is comprised of a well or borehole with a motorized pump, using oil fuel, solar power or electricity as a source of energy. Alida (2012) found out that the common technology for this is a permanent submersible pump, used in a deep borehole. Another option is a separate pump which is only put in the water source during the pumping hours. At wells or boreholes with a motorized pump, the water is pumped into a reservoir tank at an elevated point (Appendix 1) with a pipe to the tap or to other extensions. These motorized pumps can pump deep water and therefore more suitable when the water table is low.

According to Alida (2012) the daily operation of the motorized pumps requires some small activities like checking and refilling the fuel, starting and stopping the engine, checking and cleaning air filters and tightening of nuts and bolts. Other minoring and maintenance includes greasing, replacing filters and changing oil. Major maintenance includes the replacement of engine parts like the drive belt, nozzles, injectors, gaskets, bearings, or the fuel pump.

In Siaya Sub-County of Kenya, from eighty (80) water projects constructed by various development agencies in the last two decades, 90\% were non-functional by the year 2006 according to LVSWSB Inventory Report, No.25 (Oraro, 2012). Similarly, in Nyando Sub-County, UNICEF rehabilitated more than 100 failed water projects in 2009 before initiating new ones. A common denominator in these failed projects is that all were owned and managed by communities. Successful community based operation and maintenance of rural water projects therefore remains a challenge and threatens to reverse the gains that have been made in improving quality of life for rural populations in Kenya.

\section{Statement of the Problem}

Despite there being a universal recognition for the importance of safe water in poverty alleviation and socio-economic development globally, access to safe drinking water remains low; and this is partly attributed to many water supply systems not being sustainable (Mamburi, 2014).

In spite of the improved policy, legislative and funding environment where the rural water sector development investments rose from Kenya Shillings 4.2 billion in 2004/2005 Financial Year to 
Kenya Shillings 30 billion in the 2015/2016 Financial Year; access to improved drinking water still remains low. Thus, the organizations or agencies (governmental and non - governmental) that are involved in water services provision for populations living in rural Kenya have not significantly achieved their objectives of improving access to safe drinking water.

In central Nyakach Sub-County, several water projects have been launched but a majority is dysfunctional and dilapidated beyond repair. It was against this background that the study endeavored to determine the factors that influence the sustainability of community water projects in central Nyakach Sub-County of Kisumu County.

\section{Research Questions}

The study sought to answer the following questions:

1. How does community participation influence sustainability of community owned and managed water projects in central Nyakach Sub-County?

2. How does type of water extraction technology influence the sustainability of community owned and managed water projects in central Nyakach Sub-County?

\section{Methodology}

In this section, the research approach, design, population, sample size and sampling techniques, methods of data collection and analysis have been addressed.

\section{Study Approach and Design}

This study applied the mixed methods approach comprising of quantitative and qualitative techniques. This study also adopted a descriptive cross-sectional design. The study was descriptive because it focused on describing phenomena as they were; and cross-sectional because the researcher conducted research through data collection process at one point in time (August and September, 2018).

\section{The Population of the Study}

The target population comprised of community members who participated in the construction, maintenance and management of the twenty five community based water projects in central Nyakach Sub-County. This gave us a total population of 320 residents. It is from this population that a representative sample was drawn.

\section{Sample Size Determination and Sampling Technique}

According to Sekaran (2006), sample size is governed by the extent of precision and confidence desired to determine results. The sample size was determined according to Krejcie and Morgan (1970) survey table of samples that recommends a sample size of 175 respondents for a population of 320, at $95 \%$ confidence with 5.0\% margin of error (See Appendix 2).

Sampling technique is the actual procedure that is followed to obtain the individual members of the sample to represent the population (Kothari, 2003). This study employed purposeful sampling technique to select the individual respondents who took part in the construction, maintenance and 
management the water projects in Nyakach Sub-County. Purposeful sampling was used to select seven (7) respondents from each of the 25 water projects. The seven (7) respondents were selected to include one (1) Water Management Committee Member (WMCM) from each project and the administrator for each of the seven administrative units in Nyakach Sub-County.

\section{Methods of Data Collection}

The researcher triangulated various methods to collect data. These were observation, interviews with key informants, document review, questionnaire and focus group discussion. The logic of triangulation is that one method can be used to verify data of another method within a single study (Kothari, 2003). This enhanced the validity of this study.

\section{Research Instruments}

Research instruments are the tools that are used to collect data. The questionnaire was one of the tools that were used for collecting data for this study. The questionnaire is an important device in gathering data from widely scattered sources. Since the data were gathered from a widely spread sample of 175 respondents spread across 25 water projects; it was necessary to include the questionnaire as a tool for data collection. A structured questionnaire was administered to the respondents.

An interview guide was used to collect data from one (1) member drawn from each of the 25 water management committees.

There was one FGD for the seven administrative leaders. This was necessary to get their experiences of how the community participates in the water projects.

An observation schedule was used to undertake observation of the various aspects of the water projects including the type of water sources, kind of tools used and even the general condition of the projects.

A document review checklist was also another tool that was used to collect data. It had a list of documents that were reviewed and the checklist was marked off after each document had been adequately reviewed.

\section{Methods of Data Analysis}

Quantitative data was analyzed using descriptive statistics of means and percentages, while qualitative data was analyzed using content analysis technique specifically the thematic analysis technique.

\section{Research Findings}

Findings of this study were twofold as detailed subsequently.

\section{Community participation and sustainability of water projects in Central Nyakach Sub-County}

The first question of this study was to address how community participation influenced sustainability of community owned and managed water projects in Central Nyakach Sub-County. Subsequently, data was collected about various aspects community participation in water projects in 
INTERNATIONAL JOURNAL OF ACADEMIC RESEARCH IN BUSINESS AND SOCIAL SCIENCES

Vol. 9, No. 7, July, 2019, E-ISSN: 2222-6990 @ 2019 HRMARS

Central Nyakach Sub-County. The analyses were based on responses from 25 project management committee members, 8 local leaders and 142 other community members. Data were analyzed through quantitative and qualitative approaches. The results are presented below.

\section{Project Initiation}

The study sought to find out (from the 33 respondents who participated in project initiation) about who the major decision makers were at the point of the project initiation. The results are presented in table 1.

Table 1: Response on decision making on project initiation

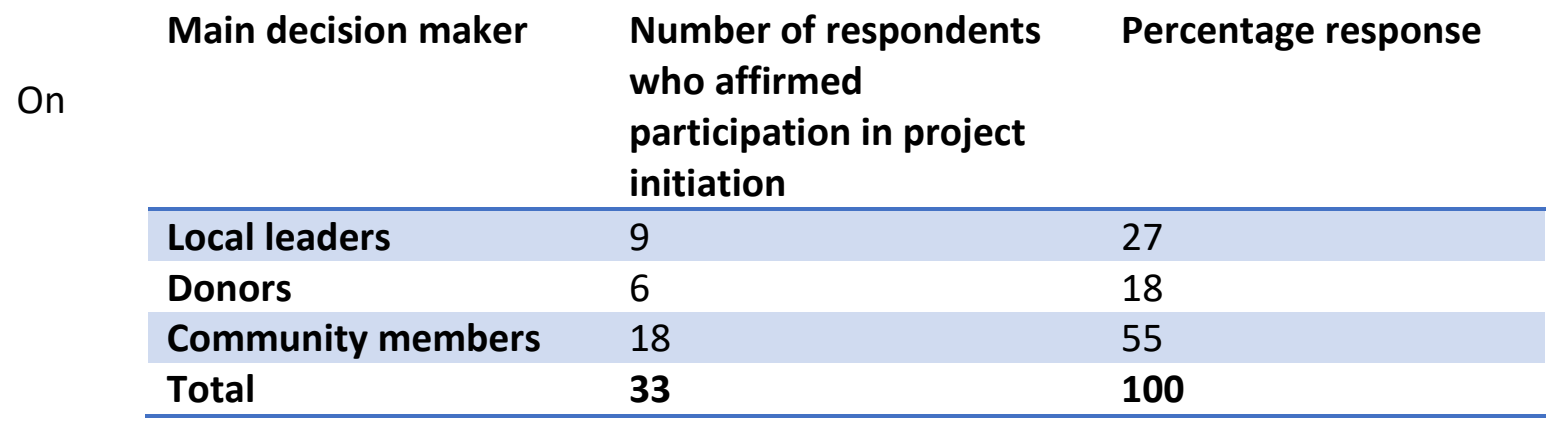

project initiation, $82 \%$ of the respondents stated that the local leaders and the community members were the main decision makers about the starting of community water projects in Central Nyakach Sub-County. This means that generally, the community had a lot of influence in initiation of the water projects.

\section{Decision on Project Location}

About the project location, 33 respondents who took part in the picking of project location were asked to indicate who had more influence in the selection of the project location. The results were as shown in table 2.

Table 2: Response on decision making on project location

$$
\text { Major decision maker Number of respondents Percentage response }
$$

On

\begin{tabular}{lll}
\hline Local leaders & 11 & 33 \\
Donors & 2 & 6 \\
\hline Community members & 20 & 61 \\
\hline Total & 33 & 100 \\
\hline
\end{tabular}

project location, $94 \%$ of the respondents who spearheaded the choice of the project location indicated that the local community (which included the local leaders) had the overall influence as to where water projects in Central Nyakach Sub-County were to be located.

The results in tables 1 and 2 indicate that the decision to initiate the water projects and the subsequent site choice was made by several groups of stakeholders in Central Nyakach Sub-County. On the basis of the FGDs and the interviews that were conducted, the study found that the 
INTERNATIONAL JOURNAL OF ACADEMIC RESEARCH IN BUSINESS AND SOCIAL SCIENCES Vol. 9, No. 7, July, 2019, E-ISSN: 2222-6990 @ 2019 HRMARS

community was significantly represented by its members during the consultative meetings and decision making on project location which improved community ownership of the projects. These findings are similar to those of Ababa (2013) and Roseland, Connelly, Hendrickson, David, Chris and Lithgow (2005) who argue that involving community members in a collective decision-making process could enhance community participation, ownership and hence sustainability.

\section{Role of Community During Project Implementation}

The committee members were asked to state the role played by the community during project implementation. The results are presented in Table 3.

Table 3: Role of Community in Project Implementation

\begin{tabular}{lll}
\hline Decision maker & $\begin{array}{l}\text { Number of respondents } \\
\text { who contributed }\end{array}$ & Percentage response \\
\hline $\begin{array}{l}\text { Provision of land } \\
\begin{array}{l}\text { Contributions } \\
\text { towards financing }\end{array}\end{array}$ & 175 & 100 \\
Provision of materials & 125 & 100 \\
Provision of labour & 175 & 71 \\
Logistical support & 33 & 100 \\
Food & 95 & 19 \\
\hline
\end{tabular}

The results in Table 3 indicate that the contribution made by the community towards the establishment of the water projects was in the form of land, labour, locally available materials (such as sand, gravel, poles), logistics, cooked food during construction and finances. Community contribution in terms of land came in the form of either individual or community land that was meant to benefit all the residents. This finding on community contributions in the water projects in Nyakach Sub-County concur with that of Kanyanya et al. (2014) who found similar contributions by the local community in the construction of water projects in Kakamega Sub-County of Kenya. However, monetary contributions in water projects in Nyakach Sub-County were relatively low. This could be attributed to the fact that large proportions of the initial capital outlay were funded by donors and Non-Governmental Organizations with the community members only being asked to make some nominal contribution. Nonetheless, it was not possible to obtain the actual amounts of these contributions due to unavailability of reliable project records. This is an indictment to the poor status of project documentation and archiving that was evident in all the community water projects that were studied Nyakach Sub-County. Despite the low levels of financial contributions by the community members, this study concurs with Mamburi (2014) that community members involvement in roles such as contributing resources, decision-making on the technology to be used, location of facilities, operation and maintenance of the community water projects has the potential to enhance ownership and ultimately project sustainability. 
INTERNATIONAL JOURNAL OF ACADEMIC RESEARCH IN BUSINESS AND SOCIAL SCIENCES

Vol. 9, No. 7, July, 2019, E-ISSN: 2222-6990 @ 2019 HRMARS

\section{Training of Water Project Committee Members}

Representatives of the committee members were asked to state the type of training that they received as a direct initiative towards project sustainability. The results are presented in table 4.

Table 4: Operations and maintenance training for committee members and local leaders

\begin{tabular}{|c|c|c|}
\hline Type of Training & $\begin{array}{l}\text { Number of } \\
\text { trainees }\end{array}$ & Percentage \\
\hline Financial Management & 15 & 46 \\
\hline Pump repairs & 9 & 27 \\
\hline Plumbing & 3 & 9 \\
\hline Tank cleaning & 6 & 18 \\
\hline Total & 33 & 100 \\
\hline
\end{tabular}

Table 4 shows operations and maintenance training that the water management committee members together with local leaders had received. Fifteen (15) members had been trained in management, nine (9) in pump repairs, three in plumbing, and six (6) storage tank cleaning. Moreover, all the 33 were trained in water level monitoring and general project security. These findings show that the committee members have been trained both in general water project management skills, the technical repair and also maintenance. From the data obtained during FGDs and interviews, this study found out that this training was tailored to help the community gain the capacity to maintain the water projects in good condition after official hand over of project to the community.

These findings are consistent with the observations by Campos (2008) who notes that training on issues like operation and maintenance empowers communities to look after water supply systems thus enhancing sustainability. Ademiluyi and Odugbesan (2008) identified lack of community education as one of the important factors which could lead to breakdown and nonsustainability of water supply projects in developing countries. It therefore implies that the committees managing water projects in central Nyakach Sub-County are well prepared to undertake repairs at the local level thereby enhancing their capacity to manage water projects sustainably. Nonetheless, it was evident that the knowledge and skills were not being applied to maintain water projects in Nyakach Sub-County.

\section{Monitoring of Water Levels}

The 25 water projects committee members who were tasked with monitoring water levels were asked to state whether they actually monitored the water levels. From qualitative data, the members confirmed that they all took part in the monitoring of water levels. About changes in the levels of water since the projects were commissioned, further responses are presented in table 5. 
INTERNATIONAL JOURNAL OF ACADEMIC RESEARCH IN BUSINESS AND SOCIAL SCIENCES

Vol. 9, No. 7, July, 2019, E-ISSN: 2222-6990 @ 2019 HRMARS

Table 5: Levels of water within the various projects

\begin{tabular}{lcclc}
\hline $\begin{array}{l}\text { Type of change in water } \\
\text { levels }\end{array}$ & $\begin{array}{l}\text { Number of Projects } \\
\text { affected }\end{array}$ & $\begin{array}{l}\text { Percentage } \\
\text { projects affected }\end{array}$ & of \\
\hline Reduced & & 15 & 60 \\
No change & 7 & 28 \\
Increased & 3 & 12 \\
& Total & $\mathbf{2 5}$ & $\mathbf{1 0 0}$ \\
\hline
\end{tabular}

The results in table 5 show that most (60\%) of water projects had receding water levels. Only 3 out of the 25 projects had an increased volume of water. The main reason for this was change in weather patterns because Nyakach Sub-County is much more prone to drought than it was in the past. These results are similar to those of Ngetich (2009) and Habtamu, (2012) who observe that most water projects decline in performance shortly after handing over. According to the respondents in this study, the reduction in the volume of water extracted from water projects in Nyakach Sub-County could be due to changing weather, inefficiencies in the technologies used, or wearing off of the major components of the pumps.

\section{Maintenance of Water Projects}

Respondents were asked to state who paid for the repairs of the water pumps whenever the pumps broke down. The results are presented in Table 6.

Table 6: Payment for repairs

\begin{tabular}{lcc}
\hline Source of funding & $\begin{array}{c}\text { Number of respondents } \\
\text { whose projects benefited }\end{array}$ & $\begin{array}{c}\text { Percentage of total } \\
\text { respondents }\end{array}$ \\
\hline $\begin{array}{l}\text { Management committees } \\
\text { County Government } \\
\text { Kisumu }\end{array}$ & 38 & 22 \\
NGOs & 13 & 7 \\
Community members & 25 & 14 \\
Well-wishers & 5 & 3 \\
Total & 94 & 54 \\
\hline
\end{tabular}

The results in table 6 indicate that the majority of the respondents (53\%) indicated that repairs for their water pumps whenever they broke down were paid for by well-wishers. The second largest number of respondents (38) indicated that management committees pay for repairs while NGOs came in third with 25 respondents indicating that NGOs helped to repair their pumps whenever they broke down. It should be noted that community members hardly significantly played a role in the repairs of water pumps and this was attributed to high levels of poverty in the area. Other than poverty, this situation could also be attributed to the low water tariff that households were charged when they fetched water because this money was mainly used for operational purposes; meaning that there were no savings for such repairs. These charges were 2.00 Kenya Shillings per a 20 litre jerry can container and Kenya Shillings $\mathbf{3 0 0 . 0 0}$ flat rate per momth for those who were connected through pipes. Therefore, for operations and maintenance of major 
INTERNATIONAL JOURNAL OF ACADEMIC RESEARCH IN BUSINESS AND SOCIAL SCIENCES Vol. 9, No. 7, July, 2019, E-ISSN: 2222-6990 @ 2019 HRMARS

breakdown of the community water projects in central Nyakach Sub-County, support from external sources was often relied upon. These findings resonate with Storm's (2003) findings that operation and maintenance of water services worldwide costs money and insufficient funding limits the capacity of water project stakeholders to purchase spare parts for the water pumps. This situation in which community members had not committed to repairing the pumps whenever they broke down negatively affected the sustainability of the water projects. This study also found that this scenario was replicated in many water projects in Nyakach Sub-County where some water projects had failed in under a year of their launching; while others had fallen beyond rehabilitation among other operational and maintenance related complications.

\section{Participation of Other Community Members in the Sustainability of Water Projects}

A total of 142 community members who are not in the water management committee or community leadership were asked to respond to five statements describing how they participated in the water project cycle on a 5-point-likert scale scored as 1 - Strongly Disagree (SD), 2 - Disagree (D), 3 - Neutral (N), 4 - Agree (A), 5 - Strongly Agree (SA). Descriptive statistics were computed and the results are presented in table 7.

Table 7: Community Participation in water projects in Central Nyakach Sub-County

\begin{tabular}{llllll}
\hline Community Participation & SA & A & N & D & SD \\
\hline Project planning & $20(14.1)$ & $66(46.5)$ & $18(12.7)$ & $21(14)$. & $17(12.0)$ \\
Project site selection & $30(21.1)$ & $21(14.8)$ & $19(13.4)$ & $53(37.3)$ & $19(13.4)$ \\
Project budgeting & $19(13.4)$ & $45(31.7)$ & $34(23.9)$ & $2416.9)$ & $20(14.1)$ \\
Project implementation & $61(43.0)$ & $37(26.1)$ & $10(7.0)$ & $16(11.3)$ & $18(12.7)$ \\
Monitoring and evaluation & $46(32.4)$ & $25(17.6)$ & $28(19.7)$ & $18(12.7)$ & $25(17.6)$ \\
\hline
\end{tabular}

In table 7, the number of respondents is given with the corresponding percentage respondents in brackets. Based on the data in table 7 , the study found out that over $50 \%$ of the respondents participated in the various key processes of the project namely project planning, project site selection, project budgeting, project implementation, monitoring and evaluation. This was above average participation. This finding is consistent with that of Kanyanya (2014) who found that community participation in project cycle management is critical for it helps to create self-reliant and empowered communities. Ananga (2015) observes that community participation in projects enhances ownership of community initiatives hence the water projects sustainability. Study findings by Oino, et al. (2015) lend credence to the above findings as these researchers also found that community participation is key to the sustainability of projects as it is out of genuine involvement of local people as active participants and equal partners whose concerns and experience can lead to the project's success. According to Mwangangi and Wanyoike (2016), community members' involvement in all the project phases from planning through to the building and management of the community water projects would enhance their ownership and sustainability. These findings are consistent with those of Rimbera (2012) that community participation enhances skills development and a sense of ownership that leads to effective implementation, actualization, maintenance, and sustainability of projects. 
INTERNATIONAL JOURNAL OF ACADEMIC RESEARCH IN BUSINESS AND SOCIAL SCIENCES Vol. 9, No. 7, July, 2019, E-ISSN: 2222-6990 @ 2019 HRMARS

\section{Water Extraction Technology}

Information was sought from the management committee members on the projects' water extraction technology, reservoir capacity and project capital cost associated with each project. A sample of 6 projects showing the least and most expensive projects was used. The data is presented in Table 8.

Table 8: Project water extraction technology, reservoir capacity and capital Cost

\begin{tabular}{llllll}
\hline Project & $\begin{array}{l}\text { Year } \\
\text { started }\end{array}$ & $\begin{array}{l}\text { Extraction } \\
\text { Technology }\end{array}$ & $\begin{array}{l}\text { Reservoir } \\
\text { Capacity } \\
\text { (litres) }\end{array}$ & $\begin{array}{l}\text { Initial } \\
\text { Capital } \\
\text { (Ksh) }\end{array}$ & $\begin{array}{r}\text { Project } \\
\text { Cost }\end{array}$ \\
\hline Olwalo & 2006 & Solar pump & 50,000 & 5 million \\
Kajunga & 2012 & Solar pump & 50,000 & 13 million \\
Kogola - Pedo & 2005 & Hand pump & ---- & 1.5 million \\
Kogelo & 2005 & Hand pump & ---- & 1.5 million \\
Ragen RC & 2007 & Hand pump & ---- & 1.5 million \\
Anyango-Oloo & 2009 & Solar Pump & 50,000 & 9 million \\
Ragen community & 2015 & Solar pump & 50,000 & 9 million \\
\hline
\end{tabular}

Results in Table 8 indicate that the serviceable water projects in Central Nyakach Sub-County have been in existence since 2006 (12 years) and 2015 (3 years), implying that for these particular projects, the systems are functional. This study also found out that there are two major modes of water extraction technologies in use, namely solar pumps and hand pumps. The capacity of the solar pumped system reservoirs was 50,000 liters while that of the hand pumps could not be quantified because no reservoirs were constructed to hold water prior to distribution. It was also evident that the solar system water projects had far much higher initial capital costs of investment than the hand pumped systems. This is attributed to the fact that the solar system has a number of components such as the solar panel stands, water pipes being laid, reservoirs and water kiosks. The hand pump water systems had relatively low initial capital costs averaging 1,500,000.00 (One Million Five Hundred Thousand Kenya Shillings) compared to the solar pump that averaged 9 million Kenya shillings.

Examples of the solar and hand pumps in Nyakach Sub-County water projects are displayed in figures 1 and 2.

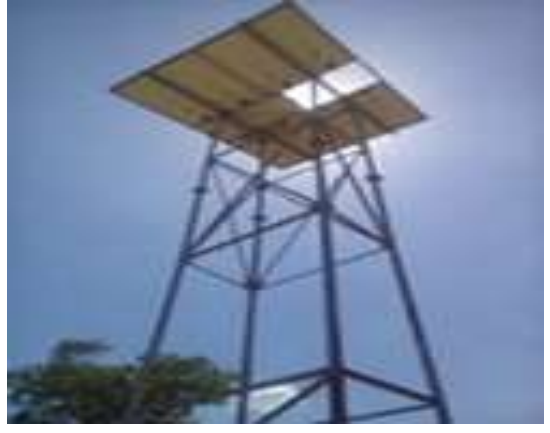

Figure 1: Solar pump

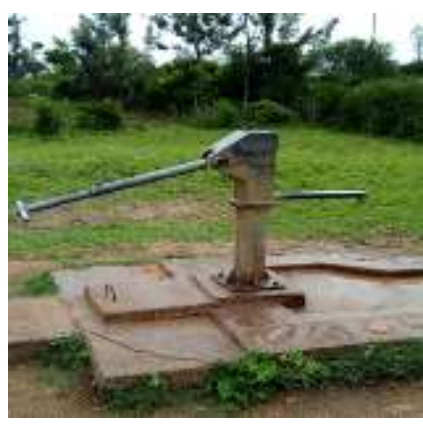

Figure 2: Hand pump 
INTERNATIONAL JOURNAL OF ACADEMIC RESEARCH IN BUSINESS AND SOCIAL SCIENCES Vol. 9, No. 7, July, 2019, E-ISSN: 2222-6990 @ 2019 HRMARS

\section{Influence of Water Extraction Technology on the Sustainability of Community Water Projects}

The second question of this study related to the influence of water extraction technology on the sustainability of community operated water projects in central Nyakach Sub-County. To achieve this objective, the respondents were asked to rate five statements describing aspects of Water extraction technology on a 5-point-likert scale scored as 1 - Strongly Disagree (SD), 2 - Disagree (D), 3 - Neutral (NU), 4 - Agree (A), 5 - Strongly Agree (SA). Descriptive statistics were computed and the results are presented in Table 9.

Table 9: Water Extraction Technology and the sustainability of community water projects

\begin{tabular}{|c|c|c|c|c|c|}
\hline Water Extraction Technology & SA & A & NU & $\mathrm{D}$ & SD \\
\hline $\begin{array}{l}\text { I took part in the decision on } \\
\text { choice of technology. }\end{array}$ & $12(8.5)$ & $18(12.4)$ & $25(17.2)$ & 39 (26.9) & $48(33.1)$ \\
\hline Pumps frequently break down. & $30(21.1)$ & $21(14.8)$ & $19(13.4)$ & $53(37.3)$ & 19 (13.4) \\
\hline $\begin{array}{l}\text { There is routine maintenance of } \\
\text { the water project machines. }\end{array}$ & $13(9.2)$ & $30(21.1)$ & $19(13.4)$ & $54(37.3)$ & $19(13.4)$ \\
\hline Spare parts are available & $53(37.3)$ & $59(41.5)$ & $18(12.7)$ & $10(8.5)$ & $2(1.4)$ \\
\hline $\begin{array}{l}\text { The water pumping machines are } \\
\text { easy to operate }\end{array}$ & $20(14.1)$ & $31(21.8)$ & $24(21.8)$ & $50(35.2)$ & $17(12.0)$ \\
\hline
\end{tabular}

Table 9 shows that majority of the respondents indicated that the water pumps frequently broke down and that the water extraction machines were not easy to operate. This was a big challenge to the operation and maintenance of the water projects. This finding resonates with that of Kanyanya of (2014) that the use of appropriate technologies and relevant training are integral to the local level operation and maintenance. There is also a strong link of this finding with that of Mamburi (2014) who found that the aspects of technology used such as cost and availability of spare parts, ease of operation and maintenance as well as user acceptability are paramount to sustainability of community water projects in central Nyakach Sub-County.

In brief, this study found that the water extraction technology for the water projects in Nyakach Sub-County was appropriate. However, there were no plans for routine maintenance of the water infrastructure (due to high cost of repair) and most of the water users had not been trained on how to operate the machines. This partly accounted for the failure of the 19 water projects. Thus, although there was enabling technology for water extraction, the high cost of repairing the machines negatively affected the sustainability of a majority of the water projects leading to their failure.

\section{Conclusion}

This paper concludes that community participation during the initiation, planning, implementation, and monitoring of water projects in Nyakach Sub-County helped to successfully construct the projects. In this case, community members' involvement in the project was noted in roles such as contribution of resources, decision-making on the technology to be used, location of facilities, operation and maintenance of the community water projects, among others. However, lack of funds for project maintenance led to the failure of a majority of the projects; where 19 out of the 25 projects 
had failed. In the 6 projects that were still operating, members had come up with a way of funding repair of project machines and equipment.

This paper also concludes that water extraction technologies were adopted for water projects in Nyakach Sub-County where solar and hand pumps were the two main water extraction technologies that were applied. In the 6 projects where this technology was well maintained, the projects were operational. The failure of the 19 projects was attributed to lack of plans for routine maintenance of the water infrastructure and that most of the water users had not been trained on how to operate the machines. Moreover, it was established that the high cost of repairing the machines negatively affected their sustainability leading to their failure.

Generally, this paper concludes that community participation in aforementioned ways together with appropriate water extraction technology contributed to the sustainability of the 6 water projects that were operational at the time of the study. The paper further concludes that the major challenges to sustainability of the water projects were the lack of funds, high cost of repairs, lack of certain spare parts for the machines, and operation of water pumps by people who had not received any training. This explained why only 19 out of 25 water projects were not working at the time of this study in September of 2018.

\section{Contribution of this Study}

The significance of this study can be broadly addressed in two ways. Theoretically, this study broadens the horizon of the available literature that explains factors that influence the sustainability of community operated water projects with examples drawn from Central Nyakach Sub-County of Kenya. Once published, this literature will be available for every interested party.

In the contextual dimension, this study has endeavoured to address some of the drivers and challenges of sustaining community operated water projects, with reference to community participation as well as water extraction technology. In this case, agencies and individuals that deal with community operated water projects can draw useful lessons from the six successful community operated water projects in Nyakach Sub-County of Kenya; as well as the 19 failed ones. Such lessons can be used as a springboard for undertaking future community operated water projects; whereby the successes can be replicated while solutions are formulated to address the identified challenges.

\section{Recommendations and Policy Implications}

Based on the findings of this study, this paper recommends as follows:

8.1 Government of Kenya ought to - by way of policy - clarify its role in the community run water projects so that communities in turn clearly understand and assume their role in the running of the water projects that they initiate. This has the potential to empower communities that put up water projects to then go ahead and play their role effectively to ensure that once such a projects are initiated, they ought to be given support by the community in order to serve the intended purpose.

8.2 Community water project management committees ought to effectively take up their responsibility of managing and sustaining community initiated water projects without expecting that the Government of Kenya comes to take over this function. This is because the study established that part of the reason as to why many of the projects faced challenges was 
due to lack of effective management by community water project management committees. Despite having been trained, it was evident that the knowledge and skills that were given to management committee members were not being applied to maintain water projects in Nyakach Sub-County. It is envisaged that if community water project management committees take charge of the community water projects, it is possible for the communities to sustainably make use of the water projects.

8.3 Community water management committees should have a training programme for all community project water users on how to operate the water pumps as the available water extraction technology. This will reduce on frequent breakdowns of machines and their attendant high financial costs as was the case in the failed 19 community water projects in Nyakach Sub-County. This will reduce the operational costs and improve the sustainable management of community water projects.

\section{Areas of Further Study}

The current study should be replicated in the entire Country of Kenya so as to cover all community owned and managed water projects. This will provide comprehensive information on the management of community water projects and subsequently inform both policy and strategies towards achieving Sustainable Development Goal number six (6) which is about ensuring availability and sustainable management of water and sanitation for all.

\section{References}

Ababa, C. T. (2013). Factors influencing sustainability of Rural Community based water projects in Mtito Andei, Kibwezi Sub-County, Kenya. Unpublished MA Thesis of the University of Nairobi.

Ademiluyi, J. A., \& Odugbesan, I. A (2008). Sustainability and impact of community water supply and sanitation programmes in Nigeria: An overview. Africa Journal of Agricultural Research, 12, 811-817.

Ali, J. B. (2012). Determinants of community ownership of water projects in Kenya; A case of Central Division, Isiolo County. Unpublished Thesis of the University of Nairobi.

Alida, A. (2012). Financial sustainability of rural water supplies in Western Kenya Engineering and Geosciences. Delft University of Technology. MA Thesis, Netherlands.

AMCOW. (2012). Water and sanitation in Africa. Addis Ababa: AMCOW

Ananga, E. O. (2015). The Role of Community Participation in Water Production and \Management: Lessons from Sustainable Aid in Africa International Sponsored Water Schemes in Kisumu, Kenya. Graduate Theses and Dissertations.htt://scholarcommons.usf.edu/etd/5900

Beyene, A. (2010). Linking and Balancing Energy, Water, and Climate Change, an Overview. Presented at: PASI 2010 - Energy, Water and Global Climate Change as a Regional Agenda of the Americas.

Brikké, F. (2002). Operation and Maintenance of Rural Water Supply and Sanitation Systems: A Training Package for Managers and Planners. Geneva: WHO.

Creswell, J. W. (2009). Research design: Qualitative, quantitative and mixed methods approach (3rd ed.). Thousand Oaks, CA: Sage Publications, Inc. 
INTERNATIONAL JOURNAL OF ACADEMIC RESEARCH IN BUSINESS AND SOCIAL SCIENCES

Vol. 9, No. 7, July, 2019, E-ISSN: 2222-6990 @ 2019 HRMARS

Gatari, S., Mbabazi, M., \& Shukla, J.E (2006). Valuation of factors Influencing sustainability of water projects in Gahondo: A case of water projects in Muhanga District, Rwanda. European Journal of Business and Social Sciences, 5 (01), 129 - 145

GoK - Ministry of Water Resources. (1999). Sessional paper no. 1 of 1999 on national policy

on water resources management policy and development. Nairobi: GoK- Ministry of

Water Resources.

GoK. (2007). The National Water Services Strategy (NWSS) 2007 - 2015. Nairobi: Government Printers.

GoK. (2010). The constitution of Kenya. Nairobi: Government Printers.

GoK. (2012), Draft of the National Water Policy. Nairobi: Government printers.

Habtamu, A. B. (2012). Factors Affecting the Sustainability of Rural Water Supply Systems. The Case of Mecha Woreda Amhara Region, Ethiopia. Cornell University. Unpublished Thesis.

IRC - International Water \& Sanitation Centre. (2011). Lessons for Rural Water Supply. Assessing progress towards sustainable service delivery, Ethiopia.

Kanyanya, L. O. (2014). Factors influencing sustainability of community water projects in Shianda Division, Kakamega County - Kenya. Unpublished MA Thesis. University of Nairobi, Kenya.

Kanyanya. L. O, Kyalo, D. N., Mulwa, A. \& Matula, P. D. (2014) Community participation in development projects in Kenya: Analytical review of factors influencing sustainable water Projects in Shianda Division, Kakamega County. Prime Journal of Business Administration and Management (BAM) 4(8), 1552-1562.

Kothari, C. R (2003). Research methodology: Methods and techniques. New Delhi: Wiley Eastern Ltd.

Krejcie, R. V. \& Morgan, D. W. (1970). Determining sample size for research activities." Educational and Psychological Measurement. Available at http://research-advisors.com, pdf. Vol 30: 607-610. Retrieved on 13/12/17.

Macharia, E. W., Mbassana, M. \& Oduor, S. (2015). Assessing sustainability of rural water projects in Naivasha, Kenya, case study: Maraigushu Water Project. European Journal of Business and Social Sciences, 4, (07), $52-83$.

Mamburi, P. N. (2014). Factors influencing community ownership of water projects in Kenya. A case of Kinas Division, Isiolo County. Unpublished MA Thesis, University of Nairobi.

Mwangangi, P. M. \& Wanyoike, D. M. (2016). Analysis of factors affecting sustainability of community borehole water projects in Kyuso, Kitui County, Kenya. International Journal of Economics, Commerce and Management, 4, (8), 937- 971.

Mwangi, W. (2014). Determinants of Sustainability of Community Water Projects in Kieni East District, Nyeri County MA Project. University of Nairobi

Ngetich, R. C. (2009). Assessment of Factors Influencing Projects Sustainability; the Case of Community Water Projects in Keekonyokie Central Location of Kajiado North District, Kenya. Unpublished Thesis, University of Nairobi.

Oino, P. G., Kirui, K. K., Towett, G. \& Luvega, C. (2015). The dilemma in sustainability of community based projects in Kenya. Global Journal of Advanced Research. 2, (4) 757-768.

Olukotun, A. G. (2008). Achieving Project Sustainability through Community Participation.

Oraro, E. J. (2012). Determinants of Delays in Construction of Community Water Projects in District. A Case of GOK UNICEF WASH Programme. M.A Thesis. University of Nairobi. Nairobi, Kenya. 
INTERNATIONAL JOURNAL OF ACADEMIC RESEARCH IN BUSINESS AND SOCIAL SCIENCES

Vol. 9, No. 7, July, 2019, E-ISSN: 2222-6990 ¿C 2019 HRMARS

Rimbera, P. K. (2012). Determinants of Water Projects Sustainability: A case of Water Projects in Kieni East Division, Nyeri County Kenya. Unpublished Thesis of University of Nairobi.

Roseland, M., Connelly, S., Hendrickson. David, L., Chris \& Lithgow, M. (2005). Towards sustainable communities: Resources for citizens and their governments. (ed.) Gabriola Island, BC: New, Society Publishers.

Storm, A. (2003). A psychometric analysis of the Utrecht work engagement scale in the South African police service. SA Journal of Industrial Psychology, 29 (4), 62-70 SA Tydskrif vir Bedryfsielkunde.

Thematic Group. (2005). Meeting of the Thematic Group on food security and sustainable rural development. UN: New York.

United Nations. (2010). The Millennium Development Goals Report 2010. Accessed on $25^{\text {th }}$ April, 2017 from http://www.un.org/en/development/desa/publications/millenniumdevelopment-goals-report-2010.html

United Nations. (2018). The human right to water and sanitation. Accessed on 20th January, 2018 from http://www.un.org/waterforlifedecade/human_right_to_water.shtml

United Nations (2015). Sustainable development goals: 17 Goals to transform the world. Accessed on 22nd October, 2017 from

https://www.un.org/sustainabledevelopment/sustainable-development-goals/

Van Loon, A. \& Droogers, P. (2006). Water evaluation and planning system, Kitui - Kenya.

Wageningen: Generaal Foulkesweg.

WHO/UNICEF. (2012). Progress on Drinking Water and Sanitation; 2012 Update, WHO/UNICEF joint monitoring programme for water supply and sanitation, United States of America. 
INTERNATIONAL JOURNAL OF ACADEMIC RESEARCH IN BUSINESS AND SOCIAL SCIENCES Vol. 9, No. 7, July, 2019, E-ISSN: 2222-6990 @ 2019 HRMARS

\section{APPENDIX 1}

Sample of Water Storage Tanks by World Vision for Nyakach Sub-County Water Projects

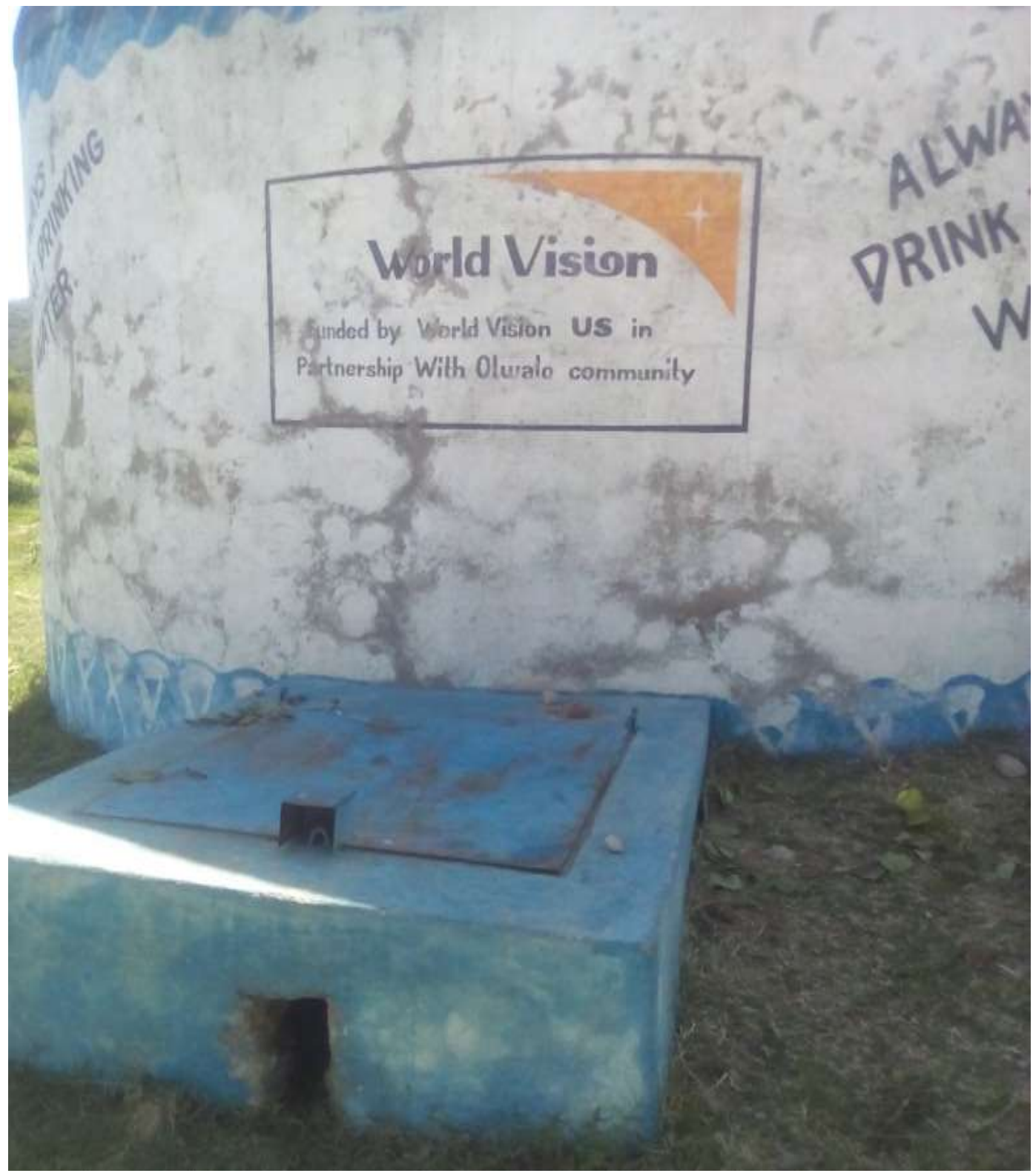


INTERNATIONAL JOURNAL OF ACADEMIC RESEARCH IN BUSINESS AND SOCIAL SCIENCES Vol. 9, No. 7, July, 2019, E-ISSN: 2222-6990 @ 2019 HRMARS

APPENDIX 2

TABLE FOR DETERMINING SAMPLE SIZE FOR A FINITE POPULATION

\begin{tabular}{|c|c|c|c|c|c|}
\hline$N$ & $S$ & $N$ & $S$ & $N$ & $S$ \\
\hline 10 & 10 & 220 & 140 & 1200 & 291 \\
\hline 15 & 14 & 230 & 144 & 1300 & 297 \\
\hline 20 & 19 & 240 & 148 & 1400 & 302 \\
\hline 25 & 24 & 250 & 152 & 1500 & 306 \\
\hline 30 & 28 & 260 & 155 & 1600 & 310 \\
\hline 35 & 32 & 270 & 159 & 1700 & 313 \\
\hline 40 & 36 & 280 & 162 & 1800 & 317 \\
\hline 45 & 40 & 290 & 165 & 1900 & 320 \\
\hline 50 & 44 & 300 & 169 & 2000 & 322 \\
\hline 55 & 48 & 320 & 175 & 2200 & 327 \\
\hline 60 & 52 & 340 & 181 & 2400 & 331 \\
\hline 65 & 56 & 360 & 186 & 2600 & 335 \\
\hline 70 & 59 & 380 & 191 & 2800 & 338 \\
\hline 75 & 63 & 400 & 196 & 3000 & 341 \\
\hline 80 & 66 & 420 & 201 & 3500 & 346 \\
\hline 85 & 70 & 440 & 205 & 4000 & 351 \\
\hline 90 & 73 & 460 & 210 & 4500 & 354 \\
\hline 95 & 76 & 480 & 214 & 5000 & 357 \\
\hline 100 & 80 & 500 & 217 & 6000 & 361 \\
\hline 110 & 86 & 550 & 226 & 7000 & 364 \\
\hline 120 & 92 & 600 & 234 & 8000 & 367 \\
\hline 130 & 97 & 650 & 242 & 9000 & 368 \\
\hline 140 & 103 & 700 & 248 & 10000 & 370 \\
\hline 150 & 108 & 750 & 254 & 15000 & 375 \\
\hline 160 & 113 & 800 & 260 & 20000 & 377 \\
\hline 170 & 118 & 850 & 265 & 30000 & 379 \\
\hline 180 & 123 & 900 & 269 & 40000 & 380 \\
\hline 190 & 127 & 950 & 274 & 50000 & 381 \\
\hline 200 & 132 & 1000 & 278 & 75000 & 382 \\
\hline 210 & 136 & 1100 & 285 & 1000000 & 384 \\
\hline
\end{tabular}

